\title{
Obtaining Transgenic Anthurium through Agrobacterium-mediated Transformation of Etiolated Internodes
}

\author{
Fure-Chyi Chen ${ }^{1}$ and Adelheid R. Kuehnle ${ }^{2}$ \\ Department of Horticulture, University of Hawaii at Manoa, 3190 Maile Way, Honolulu, HI 96822-2279
}

Additional index words. antibacterial gene, antibiotics, gene transfer, monocot, tissue culture

\begin{abstract}
Several procedures were tested in development of a gene transfer protocol for anthurium. Etiolated internode segments of anthurium cultivars 'Rudolph' and 'UH1060' were co-cultured with Agrobacterium tumefaciens LBA4404 carrying the chimeric genes neo, for antibiotic resistance, and att encoding antibacterial attacin. Assays of genomic DNA and RNA from kanamycin-resistant 'Rudolph' and DNA from 'UH1060' plantlets, recovered as soon as 1 year after culture on selection media, indicated the presence of introduced genes, including neo and att, and transcription of att. Western analysis confirmed the expression of attacin protein in calli induced from laminae of regenerated kanamycinresistant 'Rudolph' plantlets. Use of tobacco nurse cells during co-cultivation of internodes with Agrobacterium did not increase recovery of shoots under the regeneration conditions used. Improvements in culture and antibiotic selection conditions during plant development are suggested.
\end{abstract}

Anthurium hybrids are used worldwide for cut flowers and flowering potted plants. Hawaii produces about one-fifth of the world's export supply with over 10 million stems sold in 1994 (Hawaii Agricultural Statistics Service, 1995). Due to the recent devastation of many Hawaiian anthurium farms by bacterial blight caused by Xanthomonas campestris pv. dieffenbachiae McCull and Pirone, there is a need for blight resistant cultivars. A transformation method to introduce antibacterial genes into this commercial monocot is desirable to complement current hybridization breeding for disease resistance (Kamemoto et al., 1992). Such a method could allow introgression of other desirable traits, such as novel flower color or nematode resistance.

Feasibility of Agrobacterium-mediated gene transfer has been demonstrated in several monocot crops (Conner and Dommisse, 1992). We showed that etiolated internodes of Anthurium andraeanum Lind. ex André 'Rudolph' (formerly UH965) were suitable for infection by wild-type Agrobacteriurn tumefaciens (Smith and Townsend) Corm strain C58; plants were not regenerated from tumors (Kuehnle and Sugii, 1991a).

This report describes several procedures tested in development of a transformation protocol for etiolated anthurium internodes by non-tumorigenic A. tumefaciens LBA4404 using tissue culture and plant regeneration methods for Hawaiian cultivars (Kuehnle and Sugii, 1991b). The first example of transgenic anthurium plants is presented.

\section{Materials and Methods}

Plant materials and media. Etiolated internode explants of anthurium cultivars 'Rudolph' and 'UH1060' were obtained from shoots derived from nodal cuttings or excised laminae cultured in the dark on H1 (Kuehnle and Sugii, 1991 b) medium. Etiolated

Received for publication 15 Mar. 1995. Accepted for publication 6 Sept. 1995. We thank J. Jaynes for providing plasmid, peptide, and antibody, and N. Sugii and G.L, Nan for assistance, This work was supported by the State of Hawaii Governor's Agriculture Coordinating Committee Contract nos. 89-21 and 89-22 during December 1989 to January 1993 . The cost of publishing this paper was defrayed in part by the payment of page charges. Under postal regulations, this paper therefore must be hereby marked advertisement solely to indicate this fact.

'Present address: Dept. of Plant Industry, National Pingtung Polytechnic Institute, Neipu, Pingtung 91207, Taiwan.

${ }^{2}$ To whom reprint requests should be addressed. internodes were plated on media Cmod and D (Kuehnle and Sugii, 1991b) and C (identical to D with $0.5 \mathrm{mg} \cdot \mathrm{liter}^{-1}$ kinetin and auxin reduced to $1.5 \mathrm{mg} \cdot$ liter $^{-1}$ 2,4-dichlorophenoxy acetic acid) for callus proliferation, and $\mathrm{H} 1$ and $\mathrm{H} 2$ (Kuehnle and Sugii, $199 \mathrm{I}$ b) and CK7 for plant regeneration. Medium CK7 is half-strength MS (Murashige and Skoog, 1962) medium containing $0.2 \mathrm{mg} \cdot \operatorname{liter}^{-1}$ benzyladenine and $3 \mathrm{mg} \cdot \mathrm{liter}^{-1} 2$-isopentenyl adenine. Culture conditions are specified below. 'Su' tobacco callus, obtained courtesy of E.D. Earle (Cornell Univ., Ithaca N.Y. ), was grown in darkness on solidified Su (Gamborg et al., 1979) medium and subculture within 4 days before use in co-cultivation.

Kanamycin selection for callus formation. To determine suitable kanamycin concentrations for the selection of transformed cells, 40 explants each of 'Rudolph' and 'UH1060' laminae and etiolated internodes were cultured per treatment on $\mathrm{C}$ medium containing $\mathrm{O}, 25,50,75$, or $100 \mathrm{mg} \cdot \mathrm{liter}^{-1}$ kanamycin. The number of explants that formed callus in the dark at $25 \mathrm{C}$ was scored after 100 days.

Co-cultivation of 'Rudolph' explants and plant regeneration. To test transformation protocols, the plasmid pCa2Att (DestéfanoBeltrán, 1991) was obtained from J. Jaynes (Demeter Biotechnologies, Research Triangle Park, N.C.). The plasmid contains a chimeric gene, designated $\mathrm{Ca} 2 \mathrm{Att}$, comprised of att (encodes attacin, derived from the cecropia moth but lacking signal peptide sequences) under control of a double CaMV $35 \mathrm{~S}$ promoter and NOS-3' terminal sequence and inserted at the HindIII site of pBI121 (Destéfano-Beltrán, 1991; Jefferson et al., 1987; Fig. 1). After introduction into A. tumefaciens LBA4404 either by triparental mating (Ditta et al., 1980) or the freeze and thaw method (An et al., 1988), overnight cultures were grown in $5 \mathrm{ml}$ liquid YEP (An et al., 1988) medium, $\mathrm{pH} 7.2$, or LB (Miller, 1972) medium, $\mathrm{pH} 7.0$, with $25 \mathrm{mg} \cdot \mathrm{liter}^{-1}$ streptomycin and $50 \mathrm{mg} \cdot \mathrm{liter}^{-1} \mathrm{kanamycin}$ at $220 \mathrm{rpm}$, 28C. The bacterial suspension then received $200 \mu \mathrm{M}$ acetosyringone

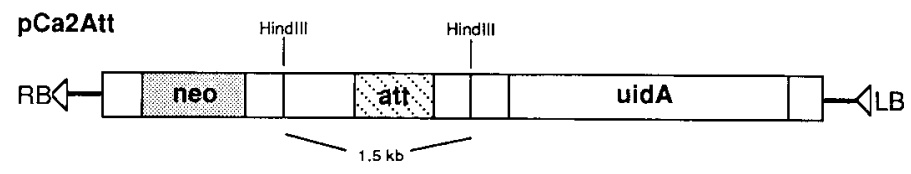

Fig. 1. T-DNA region of plasmid pCa2Att showing the order of genes for neomycin phosphotransferase II (neo), attacin (att), and $\beta$-glucuronidase (uidA), and the HindIII restriction sites. 
and was diluted with YEP, $\mathrm{pH} 5.5$, for a final concentration of 20 $\mu \mathrm{M}$ acetosyringone.

Etiolated internodes of 'Rudolph' were cut into 0.5 - to $1-\mathrm{cm}$ long segments and immersed for several minutes in bacterial suspension. Control internodes were immersed in LB medium only. Internodes and Agrobacteriurn were co-cultured on filter paper supported by 'Su' tobacco nurse cells on $\mathrm{Su}$ medium for 5 days in darkness at $25 \mathrm{C}$. Twenty internodes per treatment were then incubated in darkness on Cmod medium containing 500 $\mathrm{mg} \cdot$ liter $^{-1}$ carbenicillin or $250 \mathrm{mg} \cdot \mathrm{liter}^{-1}$ cefotaxime and $100^{-10}$ $\mathrm{mg} \cdot \mathrm{liter}^{-1}$ kanamycin with subcultures at monthly or bimonthly intervals for a total of 8 months; antibiotic was reduced to 50 mg.liter ${ }^{-1}$ kanamycin after the first 4 months. To accelerate regeneration, caulogenic calli were cultured for four months in liquid D and CK7 medium (two months each) with $50 \mathrm{mg} \cdot \mathrm{liter}^{-1}$ kanamycin at $100 \mathrm{rpm}, 25 \mathrm{C}$, under light $\left(22 \mu \mathrm{E} \cdot \mathrm{m}^{-2} \cdot \mathrm{s}^{-1}, 16 \mathrm{~h}\right.$ light $/ 8 \mathrm{~h}$ dark). All regenerated shoots were transferred to agar-solidified $\mathrm{H} 1$ medium containing $50 \mathrm{mg} \cdot \mathrm{liter}^{-1}$ kanamycin with monthly or bimonthly subcultures under light $\left(32 \mu \mathrm{E} \cdot \mathrm{m}^{-2} \cdot \mathrm{s}^{-1}, 16 \mathrm{~h}\right.$ light $/ 8 \mathrm{~h}$ dark). Plants originating from distinct calli were assigned line designations, indicated by the construct name followed by a line number (e.g., Ca2Att 1-1). Plantlets were considered kanamycinsensitive if a newly developed leaf was mottled or bleached, or if there was no further growth, and were subsequently discarded. After rooted, plants were transferred to $\mathrm{H} 2$ medium with 75 $\mathrm{mg} \cdot \mathrm{liter}^{-1}$ kanamycin.

Effect of tobacco nurse cells on 'Rudolph' and 'UH1060' transformation. Two replications of 19 to 26 etiolated internode segments of 'Rudolph' and 'UH 1060' per replicated plate were incubated for 3 days on Cmod medium with or without tobacco nurse cells (Horsch et al., 1985) during co-culture with bacteria carrying pCa2Att. Other explants (controls) were immersed in LB medium without bacteria and plated with or without nurse callus. After co-cultivation, explants from all four treatments were transferred to Cmod medium containing $500 \mathrm{mg} \cdot$ liter $^{-1}$ carbenicillin and $50 \mathrm{mg} \cdot$ liter $^{-1}$ kanamycin and were subculture monthly for 3 months. Calli were transferred onto $\mathrm{H} 1$ regeneration medium containing $50 \mathrm{mg} \cdot \mathrm{liter}^{-1} \mathrm{kanamycin}$ and $250 \mathrm{mg} \cdot \mathrm{liter}^{-1}$ carbenicillin $^{-1}$ and incubated in low light $\left(4 \mathrm{pE} \cdot \mathrm{m}^{-2} \cdot \mathrm{s}^{-1}, 16 \mathrm{~h} \mathrm{light} / 8 \mathrm{~h}\right.$ dark $)$ at $25 \mathrm{C}$ with monthly subcultures until leafy shoots regenerated. Regenerated shoots, some with roots, were removed from the callus and transferred to $\mathrm{H} 2$ medium with $75 \mathrm{mg} \cdot$ liter $^{-1} \mathrm{kanamycin}$ and maintained under higher light $\left(32 \mathrm{uE} \cdot \mathrm{m}^{-2} \mathrm{~s}^{-1}, 16 \mathrm{~h} \mathrm{light} / 8 \mathrm{~h}\right.$ dark) for further plant growth. Counts of explants forming shoots and total number of kanamycin-resistant and -sensitive plantlets were made about one year after co-cultivation. Regenerants which did not exhibit leaf bleaching or mottling compared to plants on nonselective medium were scored as resistant. Means were compared using the Students $t$ test (unpaired, one-tailed) to determine any improvement in percentage shoot formation with nurse cells compared to without nurse cells.

GUS histochemical staining. Leaf and root segments from kanamycin-resistant plantlets were excised, treated at least overnight for GUS activity according to McCabe et al. (1988), and bleached in $95 \%$ ethanol to visualize any blue tissue. A total of 19 leaf and 17 root segments from 11 'Rudolph' and 8 ' $\mathrm{UH}$ 1060' plantlets, previously transformed with construct pCa2Att, were examined.

Nucleic acid analysis using polymerase chain reaction (PCR), reverse transcriptase-PCR (RT-PCR), and genomic digests with Southern hybridization. Plant DNA extraction was according to Dellaporta et al. (1983), as described in Herrera-Estrella and Simpson (1987), using 0.5-1.2 g of in vitro 'Rudolph' leaf tissues or caulogenic 'UH 1060' callus ground in dry ice. The final DNA pellet was RNase A-treated and stored in Tris-EDTA buffer at 20C until use. DNA-PCR amplification was carried out in a TempCycler model 60 (Coy Corp., Grass Lake, Mich.) using primers for neo (Chee et al., 1989; Beck et al., 1982), uidA (Nan and Kuehnle, 1995) and att. Primers for att, based on the gene sequence from Kockum et al. (1984), were a 5' primer of 5'ATG,GAC,GCG,CAC, GGA,GCC,CTT-3' and a 3' primer of 5'TCC,GAA,GTT,AGG, CTC,CCA,AGA-3', yielding a 546 bp product. Promega Taq DNA polymerase ( 1.25 units $/ 50 \mu$ reaction) and each primer $(0.25 \mathrm{pg} / 50 \mu$ leaction $)$ were added with $1.5 \mathrm{~mm}$ $\mathrm{MgCl}$, and dNTPs at $200 \mu \mathrm{M}$ for reaction under the following conditions: initial denaturation at $94 \mathrm{C}$ for $3 \mathrm{~min}$ and 29 cycles at $94 \mathrm{C}$ for $1 \mathrm{rein}, 60 \mathrm{C}$ for $1 \mathrm{rein}$, and $72 \mathrm{C}$ for $2 \mathrm{~min}$. In the last cycle, the reaction at $72 \mathrm{C}$ was extended to $9 \mathrm{~min}$.

PCR analysis was performed for att and neo on nucleic acids isolated from other plants recovered from the same experiment as those analyzed in vitro but grown for over 2 years in the greenhouse in a 3:1 composted bark: perlite potting mix. Frozen tissues stored from plants determined transgenic by PCR were subsequently used for RT-PCR and genomic DNA restriction enzyme digestion analysis.

For extraction of leaf RNA, total nucleic acids were isolated following the procedure of Dellaporta et al. ( 1983). RNA was precipitated with 2 M lithium chloride and DNase treated once using the conditions of Zaccomer et al. ( 1993). First strand cDNA was generated through reverse transcriptase using $1.5 \mu \mathrm{g}$ RNA with a 3' att primer of 5'-GAG,AAT,CCG, AAG,TTA,GGC,TC3' specific for detection of att sequences. Reaction conditions were according to the Gene Amp Kit (Perkin-Elmer Cetus, Norwalk, Corm.). Second strand cDNA synthesis and amplification proceeded with addition of a $5^{\prime}$ att primer of $5^{\prime}$ CTT,ACG,CTC,AAC, TCC,GAT,GG-3' $(0.25$ pg/100 $\mu \mathrm{l}$ reaction) under PCR conditions as described for DNA. Cycling was extended and modified for the TempCycler II (Coy Corp.): initial denaturation at $94 \mathrm{C}$ for $1 \mathrm{~min}$ and 45 cycles at $94 \mathrm{C}$ for 30 see, $60 \mathrm{C}$ for 30 see, and $72 \mathrm{C}$ for 1 rein, extended to $5 \mathrm{~min}$ in the final cycle. This second set of att primers yields a 533 bp product.

DNA-PCR and RT-PCR products were separated by agarose gel electrophoresis and visualized using standard procedures. Southern hybridization (Maniatis et al., 1982) was performed to verify the amplified fragments. Bands in the blotted membrane were labeled and visualized using the Genius Nonradioactive Kit (Boehringer Mannheim Biochemical).

For genomic DNA restriction digestion analysis, about $10 \mu \mathrm{g}$ plant DNA were digested with HindIII according to manufacturer's directions (Promega, Madison, Wis.), separated, blotted, and bands visualized as described above.

Western analysis. Protein extraction from in vitro leaves of regenerated plants yielded insufficient quantities. Total protein was isolated instead from kanamycin-resistant calli newly formed on lamina excised from regenerated plants. Calli were obtained from six kanamycin-resistant regenerated plants representing 'Rudolph' lines Ca2Att 1-2, Ca2Att 1-3, and Ca2Att 1-4 using C medium containing $50 \mathrm{mg} \cdot$ liter $^{-1}$ kanamycin (this selection level inhibits lamina callusing by nontransformants). Protein from nonselected callus of one control plant was also used. Samples of $60 \mu \mathrm{g}$ total protein, as determined by the Lowry method (Lowry et al., 195 1), were denatured and separated by sodium dodecyl sulfate-polyacry lamide gel electrophoresis (SDS-PAGE). Partially purified cecropia attacin, $4.5 \sim \mathrm{g}$, (J. Jaynes, Demeter Biotechnologies) containing the $25 \mathrm{kDa}$ native peptide served as a reference. Protein was electroblotted and immunodetected as 
Table 1. Callus and shoot regeneration from 'Rudolph' and 'UH1060' etiolated internodes co-cultivated with Agrobacterium tumefaciens LBA4404 with and without tobacco nurse culture.

\begin{tabular}{|c|c|c|c|c|c|c|}
\hline Nurse & Treatment & $\begin{array}{c}\text { No. explants } \\
\text { co- } \\
\text { cultured }\end{array}$ & $\begin{array}{l}\text { No. forming } \\
\text { callus }^{2}(\%)\end{array}$ & $\begin{array}{c}\begin{array}{c}\text { No. forming } \\
\text { shoots }\end{array} \\
\text { (mean \% } \% \text { SD) })^{y}\end{array}$ & $\begin{array}{c}\text { No. Km- } \mathrm{r}^{\mathrm{x}} \text { plants } \\
\text { per total regenerated } \\
(\%)\end{array}$ & $\begin{array}{c}\text { Average no. } \mathrm{Km}-\mathrm{r}^{\mathrm{x}} \\
\text { plants per explant } \\
\text { with shoots }\end{array}$ \\
\hline \multicolumn{7}{|l|}{ Rudolph } \\
\hline Yes & pCa2Att & 46 & $38(83)$ & $38(81.8 \pm 9.6)$ & $206 / 737(28)$ & 4.8 \\
\hline No & pCa2Att & 44 & $33(73)$ & $24(56.2 \pm 17.3)$ & $134 / 441(30)$ & 5.6 \\
\hline Yes & LB medium only & 45 & $39(87)$ & 0 & 0 & 0 \\
\hline No & LB medium only & 47 & $33(70)$ & 0 & 0 & 0 \\
\hline \multicolumn{7}{|l|}{ UH1060 } \\
\hline Yes & pCa2Att & 50 & $16(32)$ & $13(26.0 \pm 14.1)$ & $319 / 853(37)$ & 24.5 \\
\hline No & pCa2Att & 51 & $9(18)$ & $10(19.5 \pm 5.0)$ & $366 / 792(46)$ & 22.9 \\
\hline Yes & LB medium only & 51 & $1(2)$ & 0 & 0 & 0 \\
\hline No & LB medium only & 50 & $1(2)$ & 0 & 0 & 0 \\
\hline
\end{tabular}

${ }^{2}$ Values obtained 6 months after co-cultivation; percentage of total explants cultured.

values obtained 12 months after co-cultivation; mean of two replications.

${ }^{x} \mathrm{Km}-\mathrm{r}$, kanamycin-resistant based on green, unmottled leaves; final count on $\mathrm{H} 2$ medium with 75 mg $\mu$ liter ${ }^{-1} \mathrm{kanamycin}$.

described by Bio-Rad Labs using 400-fold diluted rabbit antiattacin antibody (J. Jaynes, Demeter Biotechnologies) and 3000fold diluted goat anti-rabbit IgG conjugated with alkaline phosphatase.

\section{Results and Discussion}

Kanamycin concentration for selection. 'Rudolph' laminae formed yellow, compact callus on medium with zero or 25 $\mathrm{mg} \cdot \mathrm{liter}^{-1}$ kanamycin. The percentage of laminae with callus per total number cultured (40) was $60 \%$ and $22.5 \%$, respectively. Concentrations of $50 \mathrm{mg} \cdot \mathrm{liter}^{-1}$ kanamycin or higher completely inhibited laminar callus formation. 'Rudolph' internodes formed callus on medium lacking kanamycin or containing 25 or 50 $\mathrm{mg} \cdot$ liter $^{-1}$ kanamycin. The percentage of internodes with caulogenic callus per total number cultured was $70 \%, 5 \%$, and $15 \%$, respectively. No callus was observed on 75 and $100 \mathrm{mg} \cdot$ liter $^{-1}$ kanamy cin. For UH 1060 laminae and internodes, explants formed callus in the absence of kanamycin (100\% and $12.5 \%$, respectively) or in the presence of $25 \mathrm{mg} \cdot$ liter $^{-1} \mathrm{kanamycin}^{(12.5 \%}$ and $2.5 \%$ respectively). Callusing of ' $\mathrm{UH}$ 1060' internode and lamina explants was completely inhibited by 50 to $100 \mathrm{mg} \cdot$ liter $^{-1}$ kanamycin. For both cultivars, calli on medium with kanamycin were substantially smaller than calli produced in the absence of kanamycin.

'Rudolph' callus formation and plant regeneration after cocultivation 'Rudolph' internodes formed callus on selection medium within one month on 19 of 20 (95\%) co-cultivated explants and on 8 of $20(40 \% 0)$ control explants treated with LB broth lacking Agrobacterium. Calli from controls were, at 1 to $2 \mathrm{~mm}$, less than half the size of those from all other treatments and lacked the yellow, compact appearance of calli on Agrobacterium-treated internodes. After 4.5 months of culture in the dark, calli in the Agrobacterium treatments produced etiolated shoots of about 4 $\mathrm{mm}$. The percentage of total explants with shoots was $20 \%$. Controls did not form shoots. Eighteen months after co-cultivation, rooted green plants were recovered from treatments with Agrobacterium.

Effect of nurse culture on transformation of 'Rudolph' and 'UH1060'. $70 \%$ to $87 \%$ of all 'Rudolph' etiolated internodes initially produced callus within 6 months (Table 1). Calli on LB broth-treated explants were less than $2 \mathrm{~mm}$ in diameter and less frequent per explant than those on Agrobacterium-treated explants that grew to $5 \mathrm{~mm}$ or larger, with or without nurse co-cultivation of 'UH1060' internodes with and culture. In the without nurse cells, $32 \%$ and $18 \%$ produced callus, respectively. A few controls showed slight callusing. Calli from 'Rudolph' and 'UH1060' explants treated only with LB medium did not produce shoots (Table 1). Many calli from explants co-cultivated with Agrobacterium regenerated shoots, some with roots; some internodes also formed shoots directly with minimal callusing. Among those regenerants whose callus origin was tracked from this and the previous experiment, 14 lines of 'Rudolph' Ca2Att and 3 lines of 'UH1060' Ca2Att were identified.

Based on callus growth data and for convenience of medium preparation, $50 \mathrm{mg} \cdot$ liter $^{-1}$ kanamycin was chosen for culture of both 'Rudolph' and 'UH1060' internodes. As the number of explants forming callus was not necessarily an indication of transformation at this selection level (controls formed some callus), the effect of nurse culture on transformation was evaluated based on number of explants with shoot production (control callus

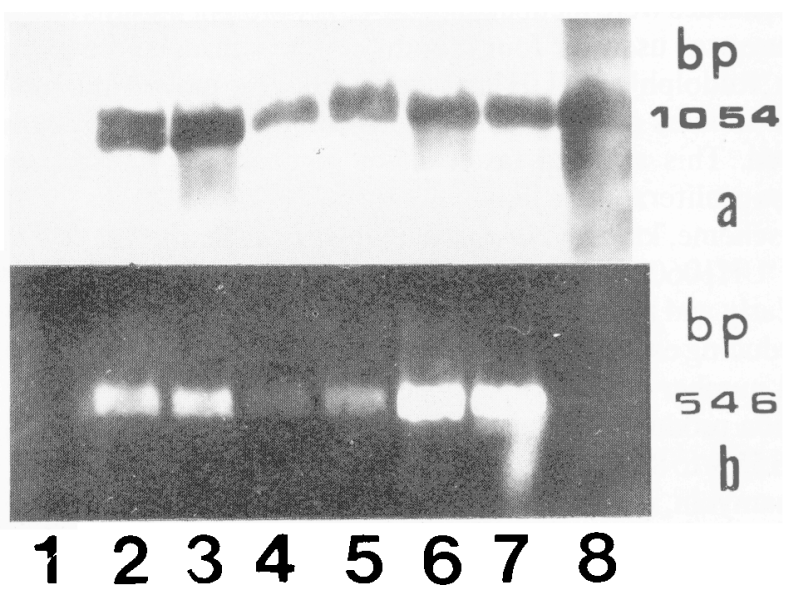

Fig. 2. (A), Southern hybridization of a PCR-amplified 1054 bp neo gene fragment and (B), gel of a PCR-amplified $546 \mathrm{bp}$ attacin gene fragment, from DNA of kanamycin-sensitive (untreated) or kanamycin-resistant (from Agrobacterium treatment) 'Rudolph' plantlets and 'UH 1060' caulogenic callus. Lanes: 1, untreated 'Rudolph'; 2, 'Rudolph' line Ca2Att 1-1; 3, 'Rudolph' line Ca2Att 12; 4, 'Rudolph' line Ca2Att 1-3; 5, 'Rudolph' line Ca2Att 1-4; 6, 'UH160' line Ca2Att2-0; 7, 'UH1060' line Ca2Att 4-0 (A) or pCa2Att plasmid (B); 8, pBII21 plasmid (A) or blank (B). 


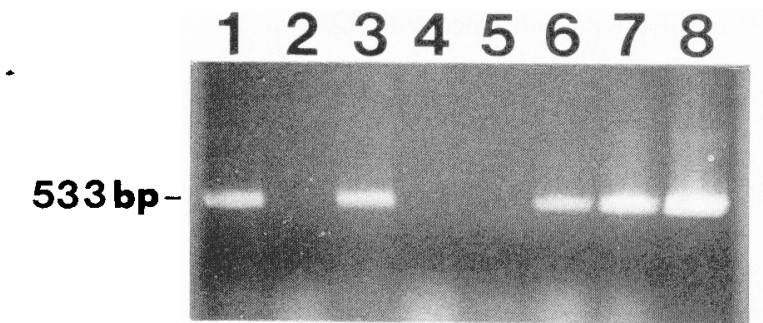

Fig. 3. RT-PCR analysis of RNA from wild-type and kanamycin-resistant (from 'Agrobacterium treatment) 'Rudolph' plants. Lanes: 1, 'Rudolph' line Ca2Att 2-2;

2, same as 1 but no reverse transcriptase; 3, 'Rudolph' line Ca2Att 10-0; 4, same as 3 but no reverse transcriptase; 5, 'Rudolph' wild-type; 6, 'Rudolph' line Ca2Att 2-

2 DNA only; 7, 'Rudolph' line Ca2Att 10-0 DNA only; 8, pCa2Att plasmid.

was not caulogenic). Shoot regeneration among Agrobacteriumtreated 'Rudolph' explants previously cultured with or without nurse cells averaged $81.8 \%$ and $56.2 \%$, with an average of 4.8 and 5.6 kanamycin-resistant plants per explant with shoots, respectively (Table 1). Although the nurse treatments produced more explants with shoots, there was a low significant difference for 'Rudolph' between treatments $(\mathrm{P}=0.1)$. While 'UH1060' also produced more shoots with nurse culture than without nurse culture (26\% vs. $19.5 \%)$, there was no significant difference between treatments $(\mathrm{P}=0.3)$. The cultivar 'UH1060' was more prolific than 'Rudolph' during shoot multiplication with an average of 22.9 to 24.5 kanamycin-resistant shoots produced per internode.

Selection on $75 \mathrm{mg} \cdot \mathrm{liter}^{-1}$ kanamycin during subsequent plant development was not sufficiently stringent, since only about $25 \%$ to $50 \%$ of the shoots recovered were kanamycin-resistant (Table 1). In some cases antibiotic-sensitive plants were not easily identifiable, as they bleached only after multiple subcultures of this slow-growing species. Therefore, the level of antibiotic that completely eliminates growth of nontransformed shoots needs to be determined and implemented during shoot regeneration. The antibiotic geneticin (G148) may be considered; $10 \mathrm{mg} \cdot$ liter $^{-1}$ geneticin completely inhibits shoot regeneration from 'UH1060' callus (A. Kuehnle, unpublished data).

In the first co-cultivation experiment with cultivar 'Rudolph' only, tissues were incubated in the dark for eight months and liquid culture was used for four months. In the subsequent experiment with 'Rudolph' and 'UH1060', explants were moved into low light three months after co-cultivation, soon after callusing was observed. This allowed faster shoot regeneration with decreased callus proliferation; a liquid culture phase was unnecessary. Using this scheme, kanamycin-resistant plantlets of cultivars 'Rudolph' and 'UH1060' were obtained within one year.

Early and high antibiotic selection pressure appeared effective in reducing escapes during production of caulogenic callus. Of the total number of 'Rudolph' internodes treated with $\mathrm{pCa} 2 \mathrm{Att}$, the portion producing at least one kanamycin-resistant shoot ranged from $55 \%$ to $83 \%$ in the nurse culture experiment using $50 \mathrm{mg} \cdot$ liter $^{-1}$ kanamycin, whereas it was $20 \%$ in the first co-cultivation experiment using $100 \mathrm{mg} \cdot$ liter $^{-1}$ kanamycin. The relatively high number of shoots on $50 \mathrm{mg} \cdot$ liter $^{-1}$ kanamycin can be explained by escapes which were manifested only later during plant development. To support the use of higher selection pressure to reduce possible escapes, a subsequent experiment using $100 \mathrm{mg} \cdot$ liter $^{-1}$ kanamycin $^{-}$ has produced caulogenic calli on only 2.5\% (1/40) of Agrobacterium -treated internodes. Regular subculture of etiolated stock plants before co-cultivation, combined with stringent selection conditions and transfer of explants into lighted culture conditions soon after callus formation should help improve the recovery of

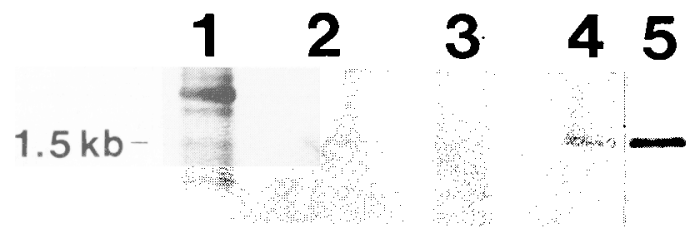

Fig. 4. Genomic Southern blot analysis of HindIII-digested DNA from wild-type and transgenic plants probed with att. Lanes: 1, molecular weight marker BstEIIlambda digest; 2, 'Rudolph' line Ca2Att 9-1; 3, 'Rudolph' wild-type; 4, 'Turkish' tobacco line 2-3 obtained after transformation with pCa2Att; 5, pCa2Att plasmid.

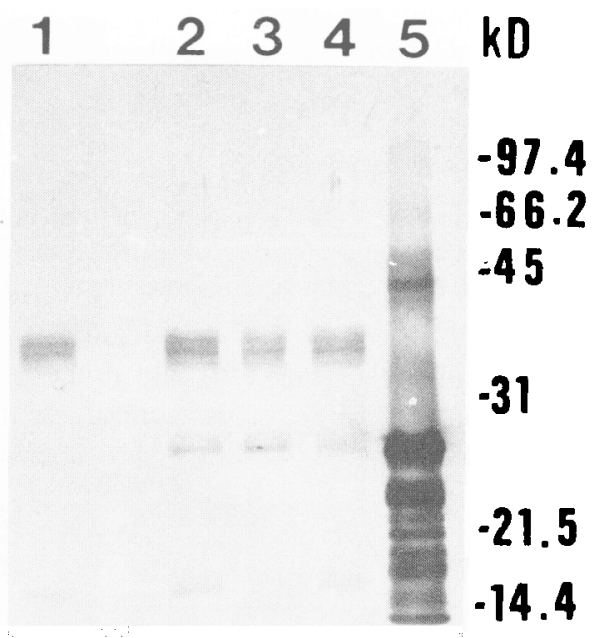

Fig. 5. Western analysis of protein extracts from callus initiated on laminae of regenerated kanamycin-sensitive (untreated) or kanamycin-resistant (from Agrobacterium treatment) 'Rudolph' plants, reacted with polyclonal antibody against attacin. Lanes: 1, untreated 'Rudolph'; 2-4, three distinct plants of kanamycin-resistant 'Rudolph' line Ca2Att 1-2; 5, partially purified cecropia insect attacin.

transgenic anthurium.

Molecular analysis. PCR-amplified DNA fragments from coculture-derived kanamycin-resistant 'Rudolph' and 'UH1060' were shown by Southern hybridization to correspond to neo and att fragments with expected sizes of $1054 \mathrm{bp}$ and $546 \mathrm{bp}$, respectively. The amplified neogenefragment of three 'Rudolph' lines (Fig. 2A, lanes 2-5) and two 'UH1060' lines (Fig. 2A, lanes 6 and 7) showed the expected size of $1054 \mathrm{bp}$ as seen in pBI121 (Fig. 2A, lane 8). An amplified att gene fragment of $546 \mathrm{bp}$ from the same lines (Fig. 2B, lanes 2-6) had similar mobility as the att fragment from pCa2Att (Fig. 2B, lane 7). No amplification of neo and att was observed in DNA from untreated 'Rudolph' (Fig. 2, lane 1). The presence of att transcripts was verified for two selected greenhouse-grown plants by RT-PCR. The amplification products showed the expected size of 533 bp (Fig. 3) and were confirmed by Southern hybridization (not shown). No amplification occurred in RNA samples lacking reverse transcriptase (Fig. 3, lanes 2 and 4) or from wild-type 'Rudolph' RNA (Fig. 3, lane 5). The expected product of $533 \mathrm{bp}$ was present in the DNA from both plants (Fig. 3, lanes 6 and 7) and from plasmid pCa2Att (Fig. 3, lane 8).

DNA from greenhouse-grown 'Rudolph' line Ca2Att 9-1 was used in genomic digest analysis. HindIII digestion generated the expected internal fragment of about $1.5 \mathrm{~kb}$ when probed for att (Fig. 4, lane 2). Bands of similar size were seen in transgenic tobacco and pCa2Att plasmid (Fig. 4, lanes 4 and 5). No hybridization was detected with wild-type 'Rudolph' DNA (Fig. 4, lane 3).

GUS activity was never detected in the anthurium leaf and root tissues examined. In some transgenic wheat and orchid plants 
containing uidA, no GUS-positive staining was observed ( Nan and Kuehnle, 1995; Vasil et al., 1992). Lack of GUS activity could be due to modifications at the gene or protein level (Diaz et al., 1992; Iturriaga et al., 1989). Effectiveness in anthurium of the uidA promoter, a single-copy CaMV 35S, is not known. It is also possible that uidA was not completely transferred during transformations. DNA from three plants recovered later from the nurse culture experiment, representing 'Rudolph' lines Ca2Att1-15 and Ca2Att 1-17 and 'UH1060' line Ca2Att 12-0, were tested by PCR for the presence of uidA. A gene fragment was amplified to the expected size in only one of three plants ( 'Rudolph' line Ca2Att117); all three of these plants were found positive for neo and att (Chen, 1993).

Since the naturally slow growth of anthurium prevented having enough leaf tissue from one plantlet for both nucleic acid and protein analysis, other regenerants derived from lines with plants found att -positive by PCR were used for western analysis. A polyclonal antibody raised against partially purified attacin from the cecropia insect cross-reacted with a $25 \mathrm{kDa}$ band in kanamy cin-resistant leaf calli from all six regenerated plants sampled. Results from 3 plants of 'Rudolph' line Ca2Att 1-2 are shown (Fig. 5, lanes 2-4). This band had the same mobility in the denaturing gel as the partially purified attacin (Fig. 5, lane 5). No cross-reaction for this specific band was detected in leaf callus from the untreated regenerant (Fig. 5, lane 1). Proteins of sizes other than $25 \mathrm{kDa}(15 \mathrm{kDa}$ and several proteins larger than 31 $\mathrm{kDa}$ ) were also recognized by the antibody and were considered not to be due to expression of att.

In summary, we have shown that protocols tested for cocultivation of etiolated internode explants with disarmed A. tumefaciens LBA4404 carrying the plasmid pCa2Att resulted in transformed anthurium plants of two distinct genotypes. Suggestions for improvement of these protocols with elimination of nurse culture during co-cultivation, more stringent selection during shoot growth, and faster plant regeneration by earlier exposure to light were made for future application. This study also showed that the attacin protein expressed in anthurium had the same apparent molecular weight as insect attacin, which indicates little or no processing of the protein in anthurium. As attacin may have only moderate antibacterial activity against the Xanthomonas responsible for anthurium blight (Chen, 1993), this gene transfer method has been successfully applied with more recently available antibacterial constructs to obtain transgenic plants for future evaluation of bacterial disease resistance and flowering characteristics.

\section{Literature Cited}

An, G., P.R. Ebert, A. Mitra, and S.B. Ha. 1988. Binary vectors, A3: 1-19. In: S.B. Gelvin, R.A. Schilperoort, and D.P.S. Verma (eds.). Plant Mol. Biol. Manual. Kluwer Academic, Dordrecht.

Beck, E., G. Ludwig, E.A. Auerswald, B. Reiss, and H. Schaller. 1982. Nucleotide sequence and exact localization of the neomycin phosphotransferase gene from transposon Tn5. Gene 19:327-336.

Chee, P.P., K.A. Fober, and J.L. Slightom. 1989. Transformation of soybean (Glycine max) by infecting germinating seeds with Agrobacterium tumefaciens. Plant Physiol. 91:1212-1218.

Chen, F.C. 1993. Genetic engineering of anthurium for bacterial disease resistance. PhD diss. Univ. of Hawaii, Honolulu.

Conner, A.J. and E.M. Dommisse. 1992. Monocotyledonous plants as hosts for Agrobacterium. Intl. J. Plant Sci. 153:550-555.

Dellaporta, S.L., J. Wood, and J.B. Hicks. 1983. A plant DNA minipreparation: Version II. Plant Mol. Biol. Rpt. 1: 19-21.
Destéfano-Beltrán, L. 1991. Introduction into tobacco plants of genes that encode some of the natural components of the humoral immune response of Hyalophora cecropia. PhD diss. Louisiana State Univ., Baton Rouge.

Diaz, I., M.J. Carmona, and F. Garcia-Olmedo. 1992. Effects of thionins on B-glucuronidase in vitro and in plant protoplasts. FEBS Lett. 296:279282.

Ditta, G., S. Stanfield, D. Corbin, and D.R. Helinski. 1980. Broad host range cloning system for Gram negative bacteria: Construction of a gene bank of Rhizobium meliloti. Proc. Natl. Acad. Sci. 77:7347-7351.

Gamborg, O.L., J.P. Shyluk, L.C. Fowke, L.R. Wetter, and D. Evans. 1979. Plant regeneration from protoplasts and cell cultures of Nicotiana tabacum sulfur mutant (Su/Su). Z. Pflanzenphysiol. 95:255-264.

Hawaii Agricultural Statistics Service. 1995. Hawaii Flowers and Nursery Products Annual Summary. Hawaii Dept. of Agr., U.S. Dept. of Agr., Honolulu.

Herrera-Estrella, L. and J. Simpson. 1987. Foreign gene expression in plants, p. 131-160. In: C.H. Shaw (cd.). Plant molecular biology: A practical approach. IRL Press, London.

Horsch, R.B., J.E. Fry, N.L. Hoffmann, M. Wallroth, D. Eichholtz, S.G. Rogers, and R.T. Fraley. 1985. A simple and general method for transferring genes into plants, Science 227: 1229-1 231.

Iturriaga, G., R.A. Jefferson, and M.W. Bevan. 1989. Endoplasmic reticulum targeting and glycosylation of hybrid proteins in trangenic tobacco. Plant Cell 1:381-390.

Jefferson, R.A., T.A. Kavanagh, and M.W. Bevan. 1987. GUS fusions: ßglucuronidase as a sensitive and versatile gene fusion marker in higher plants. EMBO J. 6:3901-3907.

Kamemoto, H., A. Kuehnle, J. Kunisaki, M. Aragaki, T. Higaki, and J. Imamura-Lichty. 1992. Breeding for new and bacterial blight resistant cultivars, p. 39-40. In: K.M. Delate and C.H.M. Tome (eds.). Proc. 5th Hawaii Anthurium Ind. Conf., HITAHR 2 Feb. 1994, Univ. of Hawaii, Honolulu.

Kockum, K., I. Faye, P. von Hofsten, J.-Y. Lee, K.G. Xanthopoulos, and H.G. Boman. 1984. Insect immunity. Isolation and sequence of two cDNA clones corresponding to acidic and basic attacins fromHylophora cecropia. EMBO J. 3:2071 -2075.

Kuehnle, A.R. and N. Sugii. 1991a. Induction of tumors in Anthurium andraeanum by Agrobacterium tumefaciens. HortScience 26: 1325 1328.

Kuehnle, A.R. and N. Sugii. 1991 b. Callus induction and plantlet regeneration in tissue cultures of Hawaiian anthuriums. HortScience 26:919921.

Lowry, O.H., N.J. Rosebrough, A.L. Farr, and R.J. Randall. 1951. Protein measurement with the Folin phenol reagent. J. Biol. Chem. 193:265275.

Maniatis, T., E.F. Fritsch, and J. Sambrook. 1982. Molecular Cloning-A Laboratory Manual. Cold Spring Harbor Laboratory, Cold Spring Harbor, N.Y.

McCabe, D.E., W.F. Swain, B.J. Martinell, and P. Christou. 1988. Stable transformation of soybean (Glycine max) by particle acceleration. Bio/ technology 6:923-926.

Miller, J.H. 1972. Experiments in Molecular Genetics. Cold Spring Harbor Laboratory, Cold Spring Harbor, N.Y.

Murashige, T. and F. Skoog. 1962. A revised medium for rapid growth and bioassay with tobacco tissue cultures. Physiol. Plant. 15:473-497.

Nan, G.L. and A.R. Kuehnle. 1995. Factors affecting gene delivery by particle bombardment of Dendrobium orchids. In Vitro Cell. Dev. Biol. 31:131-136,

Vasil, V., A.M. Castillo, M.E. Fromm, and I.K. Vasil. 1992. Herbicide resistant fertile transgenic wheat plants obtained by microprojectile bombardment of regenerable embryonic callus. Biotechnology 10:667674.

Zaccomer, B., F. Cellier, J.C. Boyer, A.L. Haenni, and M. Tepfer. 1993. Transgenic plants that express genes including the 3' untranslated region of the turnip yellow mosaic virus (TYMV) genome are partially protected against TYMV infection. Gene 136:87-94. 